\title{
The Development of a Pre-Service Teachers Model in Educational Institutions for Students in the Field of Physical Education, Faculty of Education, a Four-Year Program
}

\author{
Jirawat Khajornsilp ${ }^{1, *}$, Thitipong Sukdee ${ }^{1} \&$ Aungsumalin Kenjaturas ${ }^{1}$ \\ ${ }^{1}$ Faculty of Education, Thailand National Sports University, Chon Buri Campus, Thailand \\ *Correspondence: Thailand National Sports University 111 Sukhumvit, Nongmaidaeng, Meung, Chon Buri 20000, \\ Thailand. Tel: 66-80-967-5600. E-mail: jirawatkh@kurupatana.ac.th
}

Received: July 25, 2021

Accepted: August 15, $2021 \quad$ Online Published: August 18, 2021

doi:10.5430/wje.v11n4p31

URL: https://doi.org/10.5430/wje.v11n4p31

\begin{abstract}
The purpose of this research was to develop a pre-service teachers model in educational institutions of students in the field of physical education, Faculty of Education, a four-year program, using EDFR (Ethnographic Delphi Futures Research) techniques and focus group teaching techniques conducted by 18 experts and 12 group discussion participants with knowledge and abilities and acting as supervisors, mentors, and heads of professional experience training. The research instruments consisted of a semi-structured interview, questionnaires and group discussion guides. The statistics used in the research were median, mode and interquartile range.

The results showed that the development of pre-service teachers in a four-year physical education program consisted of four themes: (a) management of the Faculty of Education, significant in the four-year format, 25 management; (b) organizing the courses, significant in the four-year format and 38 course arrangements; (c) development of students' competency, significant in the four-year format and development of the 22 competencies; and (d) assessment and feedback, significant in the four-year format and 22-character assessment and feedback.
\end{abstract}

Keywords: pre-service teachers in school model, students in the field of physical education, four-year program

\section{Introduction}

Teachers are the most important educational resource that contributes to the success of a country's education system. For this reason, the Faculty of Education in higher education institutions with the main responsibility to produce teachers is important. In the development of the country's education, however, the production of teachers at present still has many problems, such as the lack of continuity in teacher production policies, the production of teachers that is inconsistent with social needs, the quantity and quality of teacher education teachers, the lack of cultivating teacher spirit and improving teaching skills, and a curriculum with few courses on teaching knowledge, less content, and insufficient quality of vocational training (Chanita Raksachan, 2016; Office of the Education Council of Thailand Secretariat, 2015; Supanut Sasiwuthiwat, 2016). Education has been influenced by the philosophy of education. Educational leaders and pre-service teachers should notice the availability of using this influence and educational philosophy as a tool. The teaching process of the training philosophy course has been found to be successful. It has been concluded that pre-service teachers have expressed the philosophy and education relationship with human-based views and that they prefer the "progressive training philosophy" if they want to make a new educational design. However, it has been determined that pre-service teachers did not have an idea about technology and technological developments in the Industrial Age 4.0 (Bolat \& Baş, 2018). This result is consistent with Sukdee (2021), who showed that students should have transformational leadership consisting of idealized influence, inspiration motivation, intellectual stimulation, and individualized consideration to prepare for economic changes in society and technology.

With the changing dynamics of the world and the advancement of digital technology, which affect learning in the 21 st century as well as the development of new technologies that integrate sciences and cross-cultural aspects, the aims of this education curriculum improvement are to create a modern curriculum that responds to national 
development strategies and learning in the digital world, representing the characteristics of the Education Curriculum/Education Science requirement (TQF 1; Ministry of Education, 2019). Therefore, it was made based on past research that found that there was a repetition of the course structure as well as research from lessons on teacher production in different countries, particularly the production of teaching graduates as well as brainstorming ideas and experiences of those involved in the development of the country's educational quality. The preparation of the teaching profession curriculum (TQF 1) is governed by several key principles, namely. The first principle involves the concept of the teaching professional curriculum as an integrated curriculum. In particular, it is more of a performance-based course than a content-based course with emphasis on self-learning capability and research to develop innovative learner development. Second, the curriculum structure is flexible and meets the needs of teachers and students in the present and the future. Third, when defining the course structure, teacher education institutions have the freedom to create a teacher education curriculum that is appropriate for the identity and spatial context of the educational institution, based on the learning outcomes established for each field group as a common goal, as well as to set up the curriculum structure to be flexible and reflect the identity of the learners. The fourth principle concerns promoting the creation of a modern curriculum according to international standards. There are teaching and learning structures that use technology that is consistent with learning in the digital world, and the promotion of course management teaching enables students to have professional competences as teachers. They will also have the spirit and ideals of being teachers and qualifications in line with teaching profession standards. Finally, the sixth principle involves promoting the establishment of an intensive curriculum quality assurance system so that learners meet the curriculum goals (TQF 1).

Providing a complete training course for students is necessary; as a result, students and teachers will have the knowledge and skills to become good teachers. Cassidy et al. (2018) claimed that imparting life skills to learners at an early age will help them to grow into healthy young adults with a good knowledge of how to deal with real-world issues and expectations. Thus, negligence of appropriate and effective teaching of life skills by well-prepared pre-service teachers could lead to an increase in juvenile delinquency and moral decadence. In addition, Akker's (2013) concept of the curriculum spider web proposes that curriculum content should be implemented in a way that accommodates cultural and linguistic differences and that addresses both the local and the global context. This is consistent with Vandercleyen et al. (2014), who stated, "Pre-service teachers experience emotional flux when they are involved in an organizational critical incident" (OCI). They appraise the situation as being either a challenge or a threat. Perception of self-efficacy in classroom management and the ability to seize opportunities as they emerge in an unfolding situation are determinant factors in the choice of coping strategies. The study revealed that OCIs are experienced as negative emotional episodes, which are more or less intense. In this emotional situation, the choice of a coping strategy is linked to personal factors, such as goal hierarchy and a perception of high self-efficacy, coupled with contextual factors, such as pupils' rate of activity. This is consistent with Hills and Sessoms-Penny (2021), who showed that professional development of teachers in an undergraduate instution minimizes disengagement because the skillful utilization of curriculum to differentiated instruction occurs during pre-service activities. The know-how requires attention to undergraduate developmental processes during pre-service training and in-service classroom supervision to gain the perceptions of teachers about their pre-and in-service professional development for inclusion classrooms.

From the announcement of professional experience standards of the Teachers Council of Thailand (Office of the Teachers Council of Thailand Secretariat, 2015), students must pass the teaching course in an educational institution, have held their educational degree for not less than one year and have passed the teaching practice assessment criteria in accordance with the rules, procedures and conditions prescribed by the Teachers Council of Thailand Board as follows: (a) vocational practice during study and (b) teaching practice in educational institutions in specific fields. Therefore, there has to be a need to change the teaching practice model in educational institutions from the original five-year curriculum to the four-year teaching practice. Hyndman (2017) showed that identifying and understanding the perceptions of pre-service teachers (PSTs) is vital to informing teaching practices, including interpersonal level (community influence, concentration/focus of students, inclusive teaching, misbehavior, modeling effective practice, motivation of students), physical environment level (technology/screen time, weather) and policy levels (balancing content, professional development opportunities, recognition of PE, work-life balance). With mounting demands on schools, PSTs must continually improve their preparation and readiness for teaching practical subjects, such as PE. By developing the multi-level socioecological model framework insight from the GET-PE study into the barriers for generalist PSTs to teaching PE, teacher education programs can reflect upon the socialization processes for PSTs and facilitate learning environments that meet the needs of future teachers.

Due to the change in the curriculum of the Faculty of Education in the past period from a five-year program to a 
four-year program and the changes in the world in the present era, to manage the professional experience training of students of the Faculty of Education, including their efficiency and effectiveness to respond to such changes, the researchers are interested in studying the development of pre-service teachers in educational institutions of students in the field of physical education (PE), Faculty of Education, in a 4-year course.

\section{Method}

\subsection{Objectives}

The aim of this study is to develop a pre-service teachers model in educational institutions for students in the field of physical education, Faculty of Education, a four-year program.

\subsection{Conceptual Framework}

Pre-service teachers of Physical Education Students, Faculty of Education, a 4-year

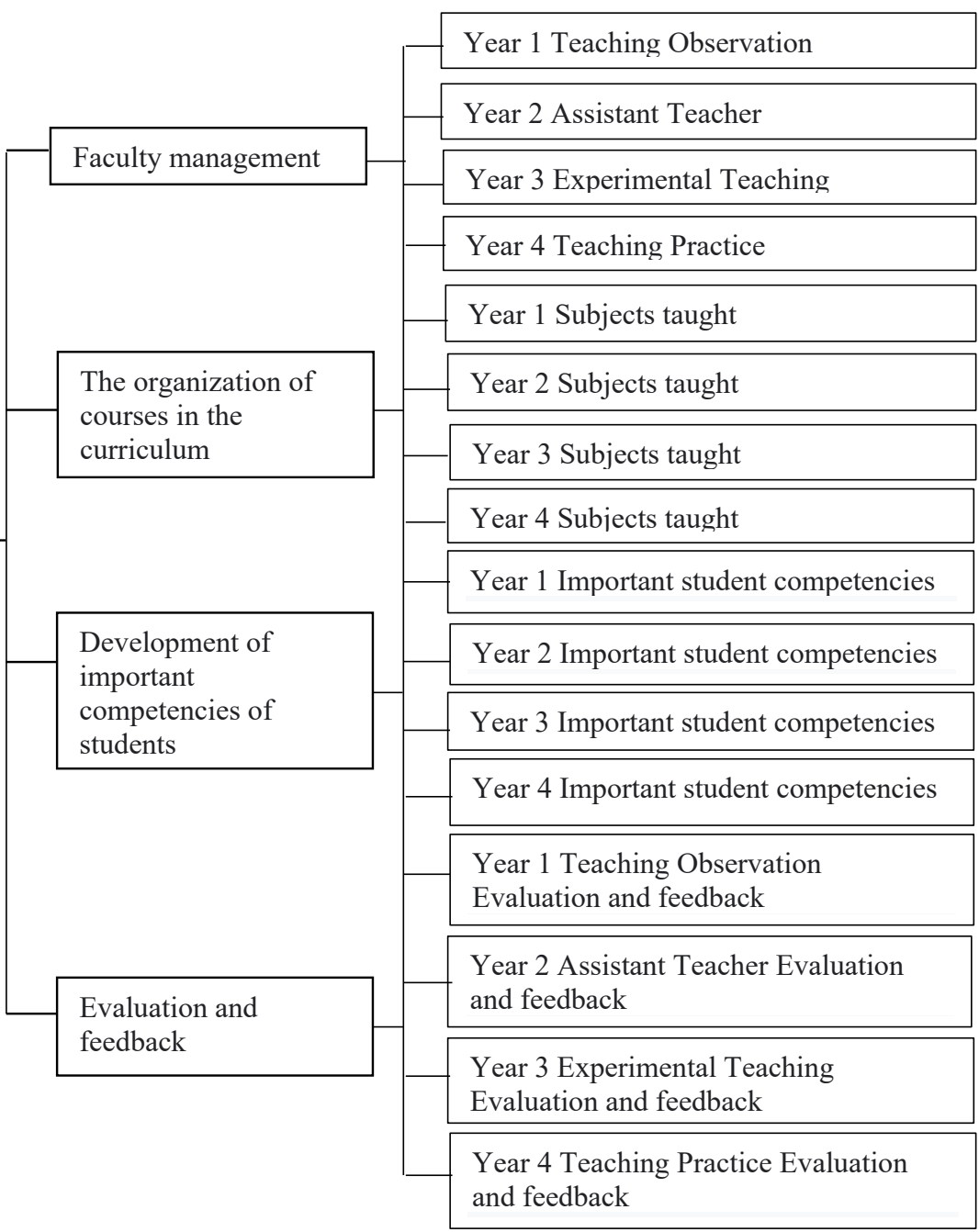

Figure 1. Conceptual Framework

The conceptual framework includes the composition of the studied variables from the concept and theory concerning the pre-service teachers in the four-year physical education program in the Faculty of Education. The following study plans were analyzed: Bachelor of Education Program of Physical Education (four-year program, updated in 2019) at Thailand National Sports University, Chonburi Campus (2020), Bachelor of Education Program Study Plan Physical Education Program (four-year program) at Srinakharinwirot University (2019), Bachelor of Education Program of Physical Education (updated in 2019) at Chiang Mai University (2019), Bachelor of Education Program of Physical 
Education (updated in 2019) at Phranakhon Si Ayutthaya Rajabhat University (2019), and Bachelor of Education Program of Physical Education (updated in 2019) at Prince of Songkhla University (2019). It consists of four sides: (a) faculty management, (b) the organization of the courses in the curriculum, (c) the development of important competencies of the students, and (d) evaluation and feedback. See Figure 1.

\subsection{Hypothesis}

Pre-service teachers model in educational institutions for students in the field of physical education, Faculty of Education, a four-year program, with empirical evidence.

\subsection{Ethical Considerations}

The researcher clearly explained the purpose and the procedures of the study to the participants and then obtained their informed consent. This study was approved by the Human Research Ethics Committee, Thailand National Sports University (certification number: TNSU 021/2564).

Every individual in the sample group was informed of the terms and conditions and agreed to participate as the sample group of this research. The researchers personally explained the details of the research and provided a consent form for participants to sign. Consent was asked of volunteers or their rightful representatives. Aliases were used instead of real names. Moreover, the names of those involved or that caused impact on the sample group were not revealed. The research results were presented as conclusions, which were of no influence to those in the sample group.

\section{Phase 1}

\subsection{Research Process}

This research included studying the concepts, documents, textbooks and research work related to pre-service teachers in the physical education field of the Faculty of Education, a four-year program, and using the information obtained to synthesize teaching practices in the educational institutions of physical education students of the Faculty of Education four-year program, creating a semi-structured in-depth interview with five questions.

Five experts examined the quality of the semi-structured in-depth interview to validate it by finding the Index of the Objective Conformity (IOC). The IOC was between 0.60 and 1.00. We selected five people who were the deans of the Faculty of Education at National Sports University, Srinakharinwirot University, Chulalongkorn University, Phranakhon Si Ayutthaya Rajabhat University, and Kasetsart University Kamphaeng Saen Campus via purposive selection. The researchers interviewed the interviewees face-to-face. Data was recorded, gathered, and sorted into the categories specified in the interviews. The data were then analyzed to find the consistency via analytic induction. The data were then analyzed using a conceptual framework to create a guideline for questions to assess the teaching practice of physical education students in the Faculty of Education four-year program in conducting research or in interpreting the data.

\subsection{Results}

The results of interviews with the five experts on the pre-service teachers model in the field of physical education, Faculty of Education, a four-year program were compiled as follows.

\subsubsection{Management of the Faculty of Education}

Year 1 pre-service teachers complete a teaching observation during their first or second semester. For teaching observation guidelines, the educational institution curriculum should be studied and analyzed. The school management structure should be studied and analyzed, as well as the study and analysis of problems and solutions of teachers in schools.

Year 2 pre-service teachers serve as an teacher assistant during the first or second semester. Guidelines for being an teacher assistant should be studied and analyzed. The teacher assistant class control document preparation of teacher assistants, the counseling of assistant teachers' teacher, the assistant's student tracking, and the inspection and the preparation of grades and documents of teacher assistants should be included.

Year 3 pre-service teachers complete periodic experimentation during the first or second semester. The method for periodic teaching should be studied, including a study and analysis of the instruction manual, periodic instruction and lesson plan. Writing a behavioral purpose, bringing the plan to the periodic teaching practice, preparing a periodic teaching activity plan, and evaluation of teaching and teaching activities for students periodically should be included.

Year 4 pre-service teachers complete their teaching practice during the first or second semester. Guidelines for 
semester teaching should be studied. There should be a study and analysis of the instruction manual for each semester, curriculum analysis toward making lesson plans per sector, preparation of lesson plans for one semester, a teacher advisor and student assessment grading.

\subsubsection{Organizing the Curriculum before Students Pre-Service Teachers}

For Year 1 pre-service teachers, the courses that the faculty must teach before the teacher observation are Thai/English Language for Communication, Moral Subjects and Ethics for Teachers Group, Relationships with Parents and Communities, Philosophy of Education and Teacher Education, History, Philosophy and Fundamentals of Physical Education and Sports, Psychology for Teachers, Sports Skills and Teaching, Citizenship Roles, Anatomy and Physiology, Introduction to Movement Studies Group, Vocational Subjects and Teachers, and Curriculum and Learning Management Group.

For Year 2 pre-service teachers, teacher assistants have defined courses that the faculty must teach before they become a teacher assistant, including Curriculum Development Academic Group, Digital Technology for Learning Innovation Development, School Physical Education Administration, Sports Skills and Teaching Group, Sports Physiology and Exercise Group, Language and Communication for Teachers, Learning Management Science Methodology Group, Educational Measurement and Evaluation Group, Mechanical Learning and Development Group, Physical Education Curriculum and Learning Management Group, and Educational Quality Assurance Academic Group.

Year 3 pre-service teachers complete periodic experimentation courses before trial teaching periodically, including English for Self-Study Group, Sports Injury Prevention and First Aid Academic Group, Sports Training and Management Group, Physical Education Measurement and Evaluation Group, Physical Education Learning Management Group, Skills and Teaching Games and Lead Games, Media and Technology for Education and Learning, and Physical Education Practice Training Group.

For the Year 4 teaching practice, there are teaching practice courses that the faculty must teach before the teaching practice, including Scouts and Red Cross Youth Groups, Sporting Events Academic Group, Research and Learning Innovation Group, Physical Education Teaching Group, Quality Assurance and Educational Management Academic Group, Physical Education Seminar, and Physical Education for People with Disabilities.

\subsubsection{The Development of Important Competencies of Students}

Year 1 pre-service teachers, who are teaching observation students, should have the following competencies: psychology competency for teachers, consulting competency, language and communication competencies for teachers, history knowledge and philosophy of physical education competencies, teacher and community role competency, and analytical and curriculum management competencies.

For Year 2 pre-service teachers, to become a teacher assistant, students should have the following competencies: classroom management competency, competency in the principles and concepts of student care and counseling, faculty integration capability, and competency in the principles and concepts of being a teacher assistant.

For Year 3 pre-service teachers, who complete periodic experimentation, students should have the following competencies: competency in curriculum analysis regarding the periodic teaching action plan, competency in organizing physical education teaching activities, competency in the principles and concepts of classroom management, competency in various teaching principles, competency in educational measurement and evaluation, and competency in the principles and concepts of stimulating students through teaching activities.

Year 4 pre-service teachers, who complete the semester teaching practice, should have significant competencies, as follows: competency in curriculum analysis of a semester teaching action plan, competency in writing lesson plans by semester, competency in measurement and evaluation in physical education, competency in grading and course documentation, and competency in teaching and learning development through research and innovation, and competency in the principles of organizing physical education projects.

\subsubsection{Evaluation and Feedback}

Year 1 pre-service teachers, who are teaching observation students, are evaluated and provided feedback by assessment of their studies, course materials, educational institutions, educational assessments, problems and solutions to student problems, and a school management teaching practice.

Year 2 pre-service teachers, who serve as teacher assistants, are evaluated and provided with feedback by assessing the behavior of the teacher assistant, assessing the classroom arrangement, assessing their document management to help teachers regularly, and assessing mentorship and student follow-up. 
Year 3 pre-service teachers, when completing their periodic experimentation, are assessed and provided with feedback with the assessment of curriculum analysis of the periodic study plan, evaluating of the writing of a lesson plan periodically, evaluating their writing of learning objectives, evaluating the writing of physical education teaching hierarchy, evaluating teaching periodically, and assessing the measurement and evaluation of students.

Year 4 pre-service teachers, who complete the teaching practice, are assessed and provided feedback by the assessing the analysis of the curriculum in a semester study plan, assessing the writing of a semester lesson plan, evaluating the writing of learning objectives, evaluating the writing of the physical education teaching hierarchy by semester, assessing the teaching throughout the semester, evaluating students' measurements and assessing results throughout the semester, evaluating the organization of student development projects, assessing the use of teaching materials to develop students, and assessing research and innovation to develop students.

\section{Phase 2}

\subsection{Research Process}

Five experts checked the quality of the semi-structured in-depth questionnaire to verify its validity by finding the Index of the Objective Conformity (IOC). The IOC was between 0.60 and 1.00 . We had the questionnaires of 18 qualified persons with the following qualifications: (a) Perform the duties of head of professional experience training in the Faculty of Education, (b) serves as a supervisor of the Faculty of Education, and (c) perform as a school mentor. We analyzed the median, mode, the difference between the median and the mode, and the interquartile range to summarize the essence of the teaching practice model in the educational institution of the students in the four-year physical education program.

\subsection{Results}

As shown in Tables 1-4, the in-depth questionnaire with 18 expert questionnaires consists of four major areas and 113- subtopics.

Table 1. Keywords and Subtopics on Management of the Faculty of Education

\begin{tabular}{|c|c|}
\hline Keywords & Subtopics \\
\hline 1. Year 1 pre-service teachers: & 1. Teaching Operations Management for all grades 1-, 2-, 3- and 4-year \\
\hline \multirow[t]{4}{*}{ Teaching observation } & 2. Teaching Practice 1: Arrange teaching observations for semester 2 \\
\hline & 3. Manage education and analyze school curriculum \\
\hline & 4. Manage the observation of the school management structure \\
\hline & 5. Manage the study of problems and solutions for teachers in schools \\
\hline 2. Year 2 pre-service teachers: & 1. Teaching Practice 2: Manage as an teacher assistant, semester 2 \\
\hline \multirow[t]{6}{*}{ Teacher assistants } & 2. Manage the teacher assistant guidelines \\
\hline & 3. Manage class control of the teacher assistant \\
\hline & 4. Manage the preparation of the teacher assistant's documents \\
\hline & 5. Manage teacher assistant counseling \\
\hline & 6. Manage follow-up checks from students of teacher assistants \\
\hline & 7. Manage the teacher assistant's grades and documentation \\
\hline 3. Year 3 pre-service teachers: & 1. Teaching Practice 3: Organizing a periodic teaching experiment, semester 2 \\
\hline \multicolumn{2}{|c|}{ Periodic experimentation 2. Manage the periodic instruction manual } \\
\hline & 3. Manage the making of the periodic lesson plan \\
\hline & 4. Manage behavioral purpose writing \\
\hline & 5. Manage the implementation of the plan into teaching practice sessions \\
\hline & 6. Organize teaching activities for periods \\
\hline & 7. Manage periodic student teaching evaluations \\
\hline 4. Year 4 pre-service teachers: & 1. Teaching Practice 4 , semester 2 \\
\hline \multirow[t]{5}{*}{ Teaching practice } & 2. Manage the instruction manual for each semester \\
\hline & 3. Manage course analysis to make lesson plans by semester \\
\hline & 4. Manage the preparation of lesson plans for one semester \\
\hline & 5. Manage being a mentor \\
\hline & 6. Manage student assessments: Scoring and grading \\
\hline
\end{tabular}


Table 2. Keywords and Subtopics on Organizing the Curriculum Before Students Practice Teaching

\begin{tabular}{|c|c|}
\hline Keywords & Subtopics \\
\hline 1. Year 1 pre-service teachers: & 1. Thai/English for Communication \\
\hline Teaching observation & $\begin{array}{l}\text { 2. Moral Subjects and Ethics for Teachers Group } \\
\text { 3. Relationships with Parents and Communities } \\
\text { 4. Philosophy of Education and Teacher Education } \\
\text { 5. History, Philosophy, and Fundamentals of Physical Education and Sports } \\
\text { 6. Sports Skills and Teaching Group } \\
\text { 7. Psychology for Teachers } \\
\text { 8. Citizenship Roles } \\
\text { 9. Anatomy and Physiology } \\
\text { 10. Introduction to Movement Studies Group } \\
\text { 11. Vocational Subjects and Teachers } \\
\text { 12. Curriculum and Learning Management Group }\end{array}$ \\
\hline $\begin{array}{l}\text { 2. Year } 2 \text { pre-service teachers: } \\
\text { Teacher assistants }\end{array}$ & $\begin{array}{l}\text { 1. Curriculum Development Academic Group } \\
\text { 2. Digital Technology for Learning Innovation Development } \\
\text { 3. School Physical Education Administration } \\
\text { 4. Sports Skills and Teaching Group } \\
\text { 5. Sport Physiology and Exercise Group } \\
\text { 6. Language and Communication for Teachers } \\
\text { 7. Learning Management Science Methodology Group } \\
\text { 8. Educational Measurement and Evaluation Group } \\
\text { 9. Mechanical Learning and Development Group } \\
\text { 10. Physical Education Curriculum and Learning Management Group } \\
\text { 11. Educational Quality Assurance Academic Group }\end{array}$ \\
\hline $\begin{array}{l}\text { 3. Year } 3 \text { pre-service teachers: } \\
\text { Periodic experimentation } 2 \text {. Spo }\end{array}$ & $\begin{array}{l}\text { 1. English for Self-Study Group } \\
\text { jury Prevention and First Aid Academic Group } \\
\text { 3. Sports Training and Management Group } \\
\text { 4. Physical Education Measurement and Evaluation Group } \\
\text { 5. Physical Education Learning Management Group } \\
\text { 6. Skills and Teaching Games and Lead Games } \\
\text { 7. Media and Technology for Education and Learning } \\
\text { 8. Physical Education Practice Training Group }\end{array}$ \\
\hline $\begin{array}{l}\text { 4. Year } 4 \text { pre-service teachers: } \\
\text { Teaching practice }\end{array}$ & $\begin{array}{l}\text { 1. Scouts and Red Cross Youth Groups } \\
\text { 2. Sporting Events Academic Group } \\
\text { 3. Research and Learning Innovations Group } \\
\text { 4. Physical Education Teaching Group } \\
\text { 5. Quality Assurance and Educational Management Academic Group } \\
\text { 6. Physical Education Seminar } \\
\text { 7. Physical Education Practice Training Group }\end{array}$ \\
\hline
\end{tabular}


Table 3. Keywords and Subtopics on the Development of Important Competencies of Students

\begin{tabular}{|c|c|}
\hline Keywords & Subtopics \\
\hline 1. Year 1 pre-service teachers: & 1. Psychological competencies for teachers \\
\hline \multirow[t]{5}{*}{ Teaching observation } & 2. Consulting competency \\
\hline & 3. Language and communication competencies for teachers \\
\hline & 4. History knowledge and philosophy of physical education competencies \\
\hline & 5. Teacher and community role competency \\
\hline & 6. Analytical and curriculum management competencies \\
\hline 2. Year 2 pre-service teachers: & 1. Classroom management competency \\
\hline \multirow[t]{3}{*}{ Teacher assistants } & 2. Competency in the principles and concepts of student care and counseling \\
\hline & 3. Facility integration capability \\
\hline & 4. Competency in the principles and concepts of being a teacher assistant \\
\hline 3. Year 3 pre-service teachers: & 1. Competency in curriculum analysis of the periodic teaching action plan \\
\hline \multirow[t]{5}{*}{ Periodic experimentation } & 2. Competency in organizing activities for teaching physical education \\
\hline & 3. Competency in the principles and concepts of classroom management \\
\hline & 4. Competency in various teaching principles \\
\hline & 5. Educational measurement and assessment performance \\
\hline & $\begin{array}{l}\text { 6. Competency in the principles and concepts of stimulating students } \\
\text { through teaching activities }\end{array}$ \\
\hline 4. Year 4 pre-service teachers: & 1. Competency in curriculum analysis of individual teaching action plans \\
\hline \multirow[t]{5}{*}{ Teaching practice } & 2. Competency in writing lesson plans by semester \\
\hline & 3. Competency in measurement and evaluation performance in physical education \\
\hline & 4. Competency in grading and course documentation \\
\hline & 5. Competency in teaching and learning development through research and innovation \\
\hline & 6. Competency in the principles of organizing physical education projects \\
\hline
\end{tabular}

Table 4. Keywords and Subtopics on Evaluation and Feedback

\begin{tabular}{|c|c|}
\hline Keywords & Subtopics \\
\hline 1. Year 1 pre-service teachers: & 1. Evaluate the study of school curriculum documents \\
\hline Teaching observation & $\begin{array}{l}\text { 2. Evaluate the study of problems and solutions to student problems } \\
\text { 3. Assessing the education of school management teaching practice }\end{array}$ \\
\hline $\begin{array}{l}\text { 2. Year } 2 \text { pre-service teachers: } \\
\text { Teacher assistants }\end{array}$ & $\begin{array}{l}\text { 1. Assessing the behavior of teacher assistant } \\
\text { 2. Assess classroom management } \\
\text { 3. Evaluate the management of documents to help teachers regularly } \\
\text { 4. Evaluate mentorship and student follow-up }\end{array}$ \\
\hline $\begin{array}{l}\text { 3. Year } 3 \text { pre-service teachers: } \\
\text { Periodic experimentation } 2 \text {. Ev }\end{array}$ & $\begin{array}{l}\text { 1. Evaluate the course analysis of the periodic study plan } \\
\text { the writing of the periodic lesson plan } \\
\text { 3. Evaluate the writing of learning objectives } \\
\text { 4. Evaluate the writing of the physical education teaching hierarchy } \\
\text { 5. Evaluate the teaching period } \\
\text { 6. Evaluate the measurements and evaluation of students }\end{array}$ \\
\hline $\begin{array}{l}\text { 4. Year } 4 \text { pre-service teachers: } \\
\text { Teaching practice }\end{array}$ & $\begin{array}{l}\text { 1. Assess the analysis of the curriculum in the semester study plan } \\
\text { 2. Evaluate writing a lesson plan for each semester } \\
\text { 3. Evaluate the writing of learning objectives } \\
\text { 4. Evaluate the writing of the physical education teaching hierarchy by semester } \\
\text { 5. Evaluate the teaching throughout the semester } \\
\text { 6. Evaluate students' measurements and assess results throughout the semester } \\
\text { 7. Evaluate the arrangement of student development projects } \\
\text { 8. Evaluate the use of teaching materials to develop students } \\
\text { 9. Evaluate research and innovation to develop students }\end{array}$ \\
\hline
\end{tabular}


Evaluation of the verifying indicators for the development of a pre-service teachers model in educational institutions for students in the physical education field of the Faculty of Education, a four-year program, concluded that all indicators' accuracy, suitability, and benefit are above the interquartile range.

\section{Phase 3}

The 12 participants assessed the pre-service teachers model in the educational institutions of students in the physical education field of the Faculty of Education Program for 4 years using a focus group.

\subsection{Results}

\subsubsection{The Results of the Opinions of the Group Discussion Participants}

The development of pre-service teachers in educational institutions for students in physical education in the Faculty of Education, a four-year curriculum, consists of four forms. For the management of the Faculty of Education, the four-tiered model is important. There are 32 managers, and the management style is divided.

The group discussion participants agreed that the management of the Faculty of Education in Year 1 had 12 important sub-items for students to be ready for pre-service teaching: (a) Teaching Operations Management for all grades 1-, 2-, 3- and 4-year; (b) Moral Subjects and Ethics for Teachers Group; (c) Relationships with Parents and Communities; (d) Philosophy of Education and Teacher Education; (e) History, Philosophy, and Fundamentals of Physical Education and Sports; (f) Sports Skills and Teaching Group; (g) Psychology for Teachers; (h) Citizenship Roles (i) Anatomy and Physiology; (j) Introduction to Movement Studies Group; (k) Vocational Subjects and Teachers; and (1) Curriculum and Learning Management Group.

The group discussion participants agreed that management of the Faculty of Education in Year 2 had seven important sub-items for students to be ready for teaching practice: (a) Manage as a teacher assistant, semester 2; (b) manage the teacher assistant guidelines; (c) manage class control of the teacher assistant; (d) manage the preparation of the teacher assistant 's documents; (e) manage teacher assistant counseling; (f) manage follow-up checks from the teacher assistant's students; and (g) manage the teacher assistant's grades and documentation.

The group discussion participants agreed that management of the Faculty of Education in Year 3 had seven important sub-items for students to be ready for teaching practice: (a) Organize a periodic teaching experiment, semester 2; (b) manage the periodic instruction manual; (c) manage the making of the periodic lesson plan; (d) manage behavioral purpose writing; (e) manage the implementation of the plan into teaching practice sessions; (f) organize teaching activities for periodic teaching; and (g) manage periodic student teaching evaluations.

The group discussion participants agreed that management of the Faculty of Education in Year 4 had six important sub-items for students to be ready for teaching practice: (a) Pre-service teachers, semester 2; (b) manage the instruction manual for each semester; (c) manage course analysis to make lesson plans by semester; (d) manage the preparation of lesson plans for one semester; (e) manage being a mentor; and (f) manage student assessments' scoring and grading.

\subsubsection{Organizing Courses before Pre-Service Teachers Can Be Divided into the Course Arrangement Format}

The group discussion participants agreed that the course arrangements of the Faculty of Education in Year 1 had 12 important sub-items for students to be ready for teaching practice: (a) Thai/English for Communication; (b) Moral Subjects and Ethics for Teachers Group; (c) Relationships with Parents and Communities; (d) Philosophy of Education and Teacher; (e) History, Philosophy, and Fundamentals of Physical Education and Sports; (f) Sports Skills and Teaching Group; (g) Psychology for Teachers; (h) Citizenship Roles; (i) Anatomy and Physiology; (j) Introduction to Movement Studies Group; (k) Vocational Subjects and Teachers; and (l) Curriculum and Learning Management Group.

The group discussion participants agreed that the course arrangements of the Faculty of Education in Year 2 had 11 important sub-items for students to be ready for teaching practice: (a) Curriculum Development Academic Group, (b) Digital Technology for Learning Innovation Development, (c) School Physical Education Administration, (d) Sports Skills and Teaching Group, (e) Sport Physiology and Exercise Group, (f) Language and Communication for Teachers, (g) Learning Management Science Methodology Group, (h) Educational Measurement and Evaluation Group, (i) Mechanical Learning and Development Group, (j) Physical Education Curriculum and Learning Management Group, and (k) Educational Quality Assurance Academic Group.

The group discussion participants agreed that the course arrangements of the Faculty of Education in Year 3 had 
eight important sub-items for students to be ready for teaching practice: (a) English for Self-Study Group, (b) Sports Injury Prevention and First Aid Academic Group, (c) Sports Training and Management Group, (d) Physical Education Measurement and Evaluation Group, (e) Physical Education Learning Management Group, (f) Skills and Teaching Games and Lead Games, (g) Media and Technology for Education and Learning, and (g) Physical Education Practice Training Group.

The group discussion participants agreed that the course arrangements of the Faculty of Education in Year 4 had seven important sub-items for students to be ready for teaching practice: (a) Scouts and Red Cross Youth Groups, (b) Sporting Events Academic Group, (c) Research and Learning Innovations Group, (d) Physical Education Teaching Group, (s) Quality Assurance and Educational Management Academic Group, (f) Physical Education Seminar, and (g) Physical Education Practice Training Group.

\subsubsection{Development of Important Competences of Students Break Down Key Performance Development}

The group discussion participants agreed that the development of student competency in Year 1 had six important sub-items for students to be ready for teaching practice: (a) Psychological competencies for teachers, (b) consulting competency, (c) language and communication competencies for teachers, (d) history knowledge and philosophy of physical education competencies, (e) teacher and community role competency, and (f) analytical and curriculum management competencies.

The group discussion participants agreed that the development of student competency in Year 2 had four important sub-items for students to be ready for teaching practice: (a) Class management competency, (b) competency in the principles and concepts of student care and counseling, (c) facility integration capability, and (d) competency in principles and concepts of being a teacher assistant.

The group discussion participants agreed that the development of student competency in Year 3 had six important sub-items for students to be ready for teaching practice: (a) Competency in curriculum analysis of the periodic teaching action plan, (b) competency in organizing activities for teaching physical education; (c) competency in the principles and the concepts of classroom management, (d) competency in various teaching principles, (e) educational measurement and assessment performance, and (f) competency in the principles and concepts of stimulating students through teaching activities.

The group discussion participants agreed that the development of student competency in Year 4 had six important sub-items for students to be ready for teaching practice: (a) Competency in curriculum analysis of individual teaching action plans, (b) competency in writing lesson plans by semester, (c) competency in measurement and evaluation performance in physical education, (d) competency in grading and course documentation, (e) competency in teaching and learning development through research and innovation, and (f) competency in the principles of organizing physical education projects.

\subsubsection{Evaluation and Feedback Split Evaluation and Providing Feedback}

The group discussion participants agreed that student assessments and feedback were important. The Faculty of Education in Year 1 had three important sub-items for students to be ready for teaching practice: (a) Evaluate the study of school curriculum documents, (b) evaluate the study of problems and solutions to student problems, and (c) assessing the education of school management teaching practice.

The group discussion participants agreed that student assessments and feedback were important. Faculty of Education in Year 2 had 4 important sub-items for students to be ready for teaching practice as follows: 1. Assessing the behavior of teacher assistant duties. 2. Assess classroom management. 3. Evaluate the management of documents to help teachers regularly. 4. Evaluate mentorship and student follow-up.

The group discussion participants agreed that student assessments and feedback were important. The Faculty of Education in Year 3 had six important sub-items for students to be ready for teaching practice: (a) Evaluate the course analysis of the periodic study plan, (b) evaluate the writing of the periodic lesson plan, (c) evaluate the writing of learning objectives, (d) evaluate the writing of the physical education teaching hierarchy, (e) evaluate the teaching period, and (d) evaluate the measurements and evaluation of students.

The group discussion participants agreed that student assessments and feedback were important. The Faculty of Education in Year 4 had nine important sub-items for students to be ready for teaching practice: (a) Assess the analysis of the curriculum in the semester study plan, (b) evaluate writing a lesson plan for each semester, (c) evaluate the writing of learning objectives, (d) evaluate the writing of the physical education teaching hierarchy by semester, (e) evaluate the teaching throughout the semester, (f) evaluate students' measurements and assess results 
throughout the semester, (g) evaluate the arrangement of student development projects, (h) evaluate the use of teaching materials to develop students, and (i) evaluate research and innovation to develop students.

\section{Discussion and Conclusions}

The development of pre-service teachers in educational institutions for students in the fielf of physical education, Faculty of Education, a four-year curriculum comprises four forms, as discussed in the following paragraphs.

First, the management style of the Faculty of Education consists of four levels. Year 1 includes teaching Operations Management for all grades 1-, 2-, 3- and 4-year. Moral Subjects and Ethics for Teachers Group should be included together with Relationships with Parents and Communities; Philosophy of Education and Teacher Education; History, Philosophy, and Fundamentals of Physical Education and Sports; Sports Skills and Teaching Group; Psychology for Teachers; Citizenship Roles; Anatomy and Physiology; Introduction to Movement Studies Group; Vocational Subjects and Teachers; and Curriculum and Learning Management Group. Year 2 includes the following: Teaching Practice 2, manage as an teacher assistant, semester 2; manage the teacher assistant guidelines; manage class control of the teacher assistant; manage the preparation of the teacher assistant's documents; manage teacher assistant counseling; manage follow-up-checks from students of teacher assistant; and manage the teacher assistant's grades and documentation. Year 3 includes the following: Teaching Practice 3, organizing a periodic teaching experiment, semester 2; manage the periodic instruction manual; manage the making of the periodic lesson plan; manage behavioral purpose writing; manage the implementation of the plan into teaching practice sessions; organize teaching activities for periods; and manage periodic student teaching evaluations. Year 4 comprises Teaching Practice 4, semester 2, as well as the following: Manage the instruction manual for each semester, manage course analysis to make lesson plans by semester, manage the preparation of lesson plans for one semester, manage being a mentor, and manage student assessments, scoring and grading.

This result is consistent with Atencio and Tan (2016), who revealed the teachers' prioritization of high elements and adventure activities within residential camps. Then, the teachers linked these "risky" and "unfamiliar" activities with transferrable learning outcomes, mostly in line with students' personal and social development. The more experienced teachers in the cohort tended to support the idea that outdoor education (OE) could be situated within local school and community environments, yet this positioning of OE within a place-based learning model reflected limited understanding of the concept. We suggest that curriculum designers and teacher educators should draw upon pre- and in-service PE teachers' perceptions of OE. It is imperative that we consider these teachers' key concerns and beliefs.

Second, organizing courses before the teaching practice can be divided into the format of the course arrangement before pre-service teachers. In Year 1 Thai/English for Communication; Moral Subjects and Ethics for Teachers Group; Relationships with Parents and Communities; Philosophy of Education and Teacher Education; History, Philosophy, and Fundamentals of Physical Education and Sports; Sports Skills and Teaching Group; Psychology for Teachers; Citizenship Roles; Anatomy and Physiology; Introduction to Movement Studies Group; Vocational Subjects and Teachers; and Curriculum and Learning Management Group should be included. In Year 2, Curriculum Development Academic Group, Digital Technology for Learning Innovation Development, School Physical Education Administration, Sports Skills and Teaching Group, Sport Physiology and Exercise Group, Language and Communication for Teachers, Learning Management Science Methodology Group, Educational Measurement and Evaluation Group, Mechanical Learning and Development Group, Physical Education Curriculum and Learning Management Group, and Educational Quality Assurance Academic Group should be added. In Year 3, English for Self-Study group, Sports Injury Prevention and First Aid Academic Group, Sports Training and Management Group, Physical Education Measurement and Evaluation Group, Physical Education Learning Management Group, Skills and Teaching Games and Lead Games, Media and Technology for Education and Learning, and Physical Education Practice Training Group should be included. Finally, Year 4 should include Scouts and Red Cross Youth Groups, Sporting Events Academic Group, Research and Learning Innovations Group, Physical Education Teaching Group, Quality Assurance and Educational Management Academic Group, Physical Education Seminar, and Physical Education Practice Training Group.

This result is consistent with Legrain et al. (2019). Although short training sessions dedicated to discovering new sports stay problematic for teacher' professional development, implementing cooperative learning (CL) pre-service teacher training designs would be a relevant alternative. Instructional knowledge would be developed mainly when they have explicit access to information concerning teacher intervention. Nevertheless, this kind of scaffolding procedure integrated into CL training designs would need to be applied repeatedly to various physical activities to have 
an impact on pre-service teachers' self-efficacy. In addition, the importance of the physical education (PE) teacher's body, particularly for teaching PE, has been highlighted in literature (González-Calvo et al., 2019). PE teachers are expected to be clear role models to students through their acts, behaviors and bodies.

Third, the development of important competencies of students break down key performance development. In Year 1, psychological competencies for teachers, consulting competency, language and communication competencies for teachers, history knowledge and philosophy of physical education competencies, teacher and community role competency, and analytical and curriculum management competencies should be added. In Year 2, class management competency, competency in the principles and concepts of student care and counseling, facility integration capability, and competency in the principles and concepts of being a teacher assistant should be included. In Year 3, competency in curriculum analysis of the periodic teaching action plan, competency in organizing activities for teaching physical education subjects, competency in the principles and concepts of classroom management, Competency in various teaching principles, Educational Measurement and Assessment Performance, and competency in the principles and concepts of stimulating students through teaching activities should be included. Year 4should include competency in curriculum analysis of individual teaching action plans, competency in writing lesson plans by semester, compentency in measurement and evaluation performance in physical education, competency in grading and course documentation, competency in teaching and learning development through research and innovation, and competency in the principles of organizing physical education projects.

This result is consistent with Süral (2019), who developed a roadmap to figure out the lesson planning competency levels of pre-service teachers in a four-year education program. Considering the reliability and validity levels, this scale can also be administered to different sample groups. The results indicated that pre-service teachers have an optimal level of competency in lesson planning.

The fourth form concerns evaluation and providing feedback. Year 1 includes evaluating the study of school curriculum documents, evaluating the study of problems and solutions to student problems, and assessing the education of school management teaching practice. Year 2 involves assessing the behavior of teacher assistant duties, assessing classroom management, evaluating the management of documents to help teachers regularly, and evaluating mentorship and student follow-up. Year 3 includes evaluating the course analysis of the periodic study plan, evaluating the writing of the periodic lesson plan, evaluating the writing of learning objectives, evaluating the writing of the physical education teaching hierarchy, evaluating the teaching period, and evaluating the measurements and evaluationg of students. Year 4 includes assessing the analysis of the curriculum in the semester study plan, evaluating writing a lesson plan for each semester, evaluating the writing of learning objectives, evaluating the writing of the physical education teaching hierarchy by semester, evaluating teaching throughout the semester, evaluating students' measurements and assessing results throughout the semester, evaluating the arrangement of student development projects, evaluating the use of teaching materials to develop students, and evaluating research and innovation to develop students.

This result is consistent with Hushman et al. (2020). These experiences can impact how pre-service teachers approach many aspects of the teaching profession. This impact includes pre-service teachers and their conceptions of assessment in their role as students, knowledge of classroom assessment (CA), data self-efficacy, and intention to engage in data-driven decision-making upon entering the profession. The study indicated that PE pre-service teachers with more positive conceptions of assessment in their student role show greater knowledge about CA, have better opinions of data, and greater intention to use data and CAs as evidence for decision-making.

In conclusion, the development of pre-service teachers in educational institutions for students in Physical Education, Faculty of Education, a 4-year course, that can be used in practice by implementing the management in four aspects, namely (a) management of the Faculty of Education, (b) organizing the curriculum before teaching practice, (c) developing the students' key competencies, and (d) evaluation and feedback. This result corresponds to Zakaria et al. (2019). Moreover, a practical micro-teaching component in teacher training programs could help pre-service teachers acquire basic teaching skills and develop self-confidence to avoid the challenges encountered by the participants in this study. Additionally, Arasomwan and Mashiya (2021) emphasized the foundation phase in pre-service teachers' experiences in teaching life skills during their teaching practice.

\section{Recommendations}

First, for the faculty and chairperson of the four-year bachelor's degree program in physical education at the University in Thailand, this research can be used as a guideline for the management of four-year undergraduate 
programs in teaching practice in educational institutions of students in the field of physical education, Faculty of Education, a four-year program.

Second, this research can lead to the development of pre-service teachers in four-year physical education program in the Faculty of Education in educational institutions regarding management of the Faculty of Education and organization of the course. The development of the students' competencies and evaluation and feedback enable students to develop as pre-service teachers throughout the four-year course of study.

\section{Suggestion for Further Research}

There should be a study of the results of pre-service teachers in educational institutions of physical education students in a four-year program, using the pre-service teachers model on a yearly basis to develop the pre-service teachers throughout the course of study.

\section{Acknowledgments}

The researchers would like to express their gratitude to Thailand National Sports University, Chon Buri Campus, for funding this research on the development a pre-service teachers model in educational institutions for students in the field of physical education, Faculty of Education, a four-year program.

\section{References}

Akker, J. V. D. (2013). A European perspective on curriculum development and innovation. In E. H. F. Law \& C. Li (Eds.), Curriculum innovations in changing societies (pp. 535-545). Sense Publishers. https://doi.org/10.1007/978-94-6209-359-1_30

Arasomwan, D. A., \& Mashiya, N. (2021). Foundation phase pre-service teachers' experiences of teaching life skills during teaching practice. South African Journal of Childhood Education, 11(1), a700. https://doi.org/10.4102/sajce.v11i1.700

Atencio, M., \& Tan, Y. S. M. (2016). Teacher deliberation within the context of Singaporean curricular change: Preand in-service PE teachers' perceptions of outdoor education. The Curriculum Journal, 27(3), 368-386. https://doi.org/10.1080/09585176.2015.1127843

Bolat, Y., \& Baş, M. (2018). The perception of the educational philosophy in the Industrial Age 4.0 and the educational philosophy productivity of teacher candidates. World Journal of Education, 8(3), 149-161. https://doi.org/10.5430/wje.v8n3p149

Cassidy, K., Franco, Y., \& Meo, E. (2018). Preparation for adulthood: A teacher inquiry study for facilitating life skills in secondary education in the United States. Journal of Educational Issues, 4(1), 33-46. https://doi.org/10.5296/jei.v4i1.12471

Chanita Raksachan. (2016). A study of the conditions and problems of production, use and development of basic education teachers that correspond to future needs. Office of the Teachers Council of Thailand Secretariat.

Chiang Mai University. (2019). Bachelor of Education Program of Physical Education (Updated course 2019). Chiang Mai University, Faculty of Education.

González-Calvo, G., Varea, V., \& Martínez-Álvarez, L. (2019). Health and body tensions and expectations for pre-service physical education teachers in Spain. Sport, Education, and Society, 24(2), 158-167. http://doi.org/10.1080/13573322.2017.1331426

Hills, D. C., \& Sessoms-Penny, S. (2021). Pre-Service professional development for inclusion teachers (EJ1296461). Research in Higher Education Journal, 40. ERIC. https://files.eric.ed.gov/fulltext/ EJ1296461.pdf

Hushman, J. C., Hushman, G., \& Gaudreault, K. L. (2020). Examining the relationship between physical education pre-service teachers' socialization and conceptions of classroom assessment. International Journal of Kinesiology in Higher Education, 4(4), 129-140. http://doi.org/10.1080/24711616.2019.1710731

Hyndman, B. P. (2017). Perceived social-ecological barriers of generalist pre-service teachers towards teaching physical education: Findings from the GET-PE study. Australian Journal of Teacher Education, 42(7), 26-46. http://dx.doi.org/10.14221/ajte.2017v42n7.3 
Legrain, P., Escalié, G., Lafont, L., \& Chaliès, S. (2019). Cooperative learning: a relevant instructional model for physical education pre-service teacher training? Physical Education and Sport Pedagogy, 24(1), 73-86. http://doi.org/10.1080/17408989.2018.1561838

Ministry of Education. (2019). Undergraduate education qualifications (Four-year course). Retrieved from http://www.mua.go.th/users/tqf-hed/news/data6/Bachelor\%20of\%20Education-4Y-2562_r.pdf

Office of the Teachers Council of Thailand Secretariat. (2015). Status of teacher production and development in Thailand. Prikwan Graphic Company Limited.

Phranakhon Si Ayutthaya Rajabhat University. (2019). Bachelor of Education Program of Physical Education (Updated course 2019). Phranakhon Si Ayutthaya Rajabhat University, Faculty of Education.

Prince of Songkhla University. (2019). Bachelor of Education Program of Physical Education (Updated course 2019). Prince of Songkhla University, Faculty of Education.

Srinakharinwirot University. (2019). Bachelor of Education Program Study Plan Physical Education Program (4-year course). Faculty of Physical Education. Srinakharinwirot University.

Sukdee, T. (2021). The development of indicators for transformational leadership of undergraduate students at Thailand National Sports University. World Journal of Education, 11(1), 94-106. https://doi.org/10.5430/wje.v11n1p94

Supanut Sasiwuthiwat. (2016). Report on the teacher personnel system reform set: Proposals for building and selecting good teachers of the new generation for upgrading the quality of education. National Development Research Institute.

Süral, S. (2019). An examination of pre-service teachers' competencies in lesson planning. Journal Education and Training Studies, 7(3), 1-13. https://doi.org/10.11114/jets.v7i3.3902

Thailand National Sports University, Chonburi Campus. (2020). Bachelor of Education Program of Physical Education (Updated course 2019). Thailand National Sports University, Chonburi Campus, Faculty of Education.

Vandercleyen, F., Boudreau, P., Carlier, G., \& Delens, C. (2014). Pre-service teachers in PE involved in an organizational critical incident: emotions, appraisal and coping strategies, Physical Education and Sport Pedagogy, 19(2), 164-178. http://doi.org/10.1080/17408989.2012.732564

Zakaria, Z., Setyosari, P., Sulton, S., \& Kuswandi, D. (2019). The effect of art-based learning to improve teaching effectiveness in pre-service teachers. Journal for the Education of Gifted Young Scientists, 7(3), 531-545. https://doi.org/10.17478/jegys.606963

\section{Copyrights}

Copyright for this article is retained by the author(s), with first publication rights granted to the journal.

This is an open-access article distributed under the terms and conditions of the Creative Commons Attribution license (http://creativecommons.org/licenses/by/4.0/). 